\title{
PEMANFAATAN SIMULASI PHET DALAM MENDUKUNG PEMBELAJARAN FISIKA MATERI RANGKAIAN LISTRIK SEARAH PADA MASA PANDEMI
}

Rudi Haryadi ${ }^{1}$, Ahmad Khotibul Umam ${ }^{2 *}$

${ }^{1,2}$ Jurusan Pendidikan Fisika, Universitas Sultan Ageng Tirtayasa, Serang, Indonesia

Corresponding author email: yumamrizqi@gmail.com

Info Artikel

Diterima:

21 Desember 202

Disetujui:

17 April 2021

Dipublikasikan:

30 Juni 2021

\begin{abstract}
Abstrak:
Tujuan penelitian ini untuk mengetahui pemanfaatan simulasi PhET dalam pembelajaran fisika pada materi rangkaian listrik searah pada masa pandemi. Metode penelitian yang digunakan yaitu jenis penelitian kualitatif deskriptif dengan studi literatur dari berbagai artikel. Hasil penelitian menunjukan bahwa simulasi PhET sangat efektif untuk diterapkan dalam mendukung pembelajaran fisika materi rangkaian listrik searah pada masa pandemi. Hal ini ditunjukan oleh data presentasi hasil belajar setelah menggunakan simulasi PhET di mana hasilnya rata-rata mengalami kenaikan. Selain itu, dari sisi misskonsepsi juga mengalami perubahan menjadi lebih baik. Siswa yang misskonsepsi jadi berkurang.
\end{abstract}

Kata kunci: Rangkaian listrik, pembelajaran fisika, simulasi PhET.

\section{Abstract:}

The purpose of this study was to determine the use of PhET simulation in physics learning on electric circuit material during the pandemic. The research method used is descriptive qualitative research with literature studies from various articles. The results showed that the PhET simulation was very effective to be applied in supporting the physics learning of unidirectional electric circuits during the pandemic. This is shown by the data on the presentation of learning outcomes after using the PhET simulation where the average results have increased. In addition, from the misconception side, it has also changed for the better. There are fewer students who have misconceptions.

Keywords: Electric circuit, physics learning, PhET Simulation. 


\section{Pendahuluan}

Indonesia merupakan salah satu negara di Dunia yang terjangkit wabah COVID-19. Pada maret 2020 Presiden Republik Indonesia Joko Widodo menyatakan bahwa terdapat kasus yang terkonfirmasi positif COVID-19. Menyikapi hal tersebut, untuk mengantisipasi penularan wabah maka dalam bidang pendidikan pemerintah mengeluarkan surat edaran nomor 4 tahun 2020 tentang pelaksanaan kebijakan pendidikan dalam masa darurat penyebaran COVID-19. Di mana salah satu isinya yaitu mengenai belajar di Rumah. Pada keadaan mendadak seperti sekarang ini diperlukan pemikiran-pemikiran yang kreatif dan inovatif dari seorang pendidik agar kegiatan pembelajaran yang meskipun dilakukan secara jarak jauh akan tetap menarik dan tidak membuat jenuh siswa. Inovasi yang dapat dilakukan untuk membantu mengatasi permasalahan pembelajaran tersebut adalah dengan menggunakan media pembelajaran (Sanjaya dan Asyhar 2012).

Media pembelajaran merupakan alat pendukung yang dapat membantu mengilulastrasikan dan menyampaikan ilmu pengetahuan menjadi lebih menarik. Hal ini merupakan salah satu solusi dari permasalahan untuk mengatasi rasa jenuh siswa dalam belajar. Karena, semakin berkembangnya zaman, teknologi berkembang dengan pesat. Berbagai lembaga telah memproduksi media pembelajaran interaktif untuk bisa digunakan dalam proses pembelajaran. Salah satunya yaitu media simulasi PhET. Media ini merupakan salah satu media interaktif yang didesain untuk bisa diakses oloeh publik. Media ini juga bisa digunakan sebagai pengganti kegiatan praktikum yang terhenti akibat adanya wabah pandemi. Selain itu, simulasi PhET ini juga bisa digunakan untuk membantu membangun pemahaman konsep siswa khususnya pada materi rangkaian listrik searah. Rangkaian listrik searah merupakan salah satu bab dalam mata pelajaran fisika yaitu pada kelas 12 yang membahas mengenai rangkaian listrik, arus listrik, tegangan listrik, hambatan listrik dan hukumhukum yang terintegrasi didalamnya.

\section{Metode Penelitian}

Metode penelitian yang digunakan yaitu jenis metode penelitian kualitatif deskriptif yang dilakukan dengan studi literatur dari berbagai artikel. Selain itu, penelitian ini dilakukan dengan menganalisis, meringkas berbagai data yang dikumpulkan melalui pengamatan yang didapatkan. Penelitian dilakukan dalam waktu 2 pekan dengan rincian di hari pertama sampai hari ke-5 itu mencari artikel yang sesuai dengan artikel. Hari ke-6-11 kegiatan bedah artikel. Di hari ke 12-14 melakukan kombinasi dan membandingkan artikel satu dengan yang lainnya kemudian setelah itu mulai menuliskannya dalam bentuk artikel review. Penelitian ini dilakukan di Rumah peneliti yaitu di daerah Cisoka-Tangerang dengan berbantuan telepon pintar dan juga laptop untuk mengakses artikel. Target sasaran yang ingin dituju ialah siswa SMA kelas 12. Di mana, pada masa pandemic ini, pembelajaran terhambat. Melalui penelitian ini, peneliti akan membuktikan dengan menyajikan berbagai data yang telah di review tentang peran simulasi PhET dalam mendukung pembelajaran pada masa pandemic khususnya pada materi rangkaian listrik searah.

\section{Hasil dan Pembahasan} berikut:

Setelah melakukan penelitian dalam bentuk review artikel, didapatkan data-data sebagai

Penerapan media laboratorium virtual PhET pada materi Hukum Ohm dapat meningkatkan prestasi belajar siswa kelas X-IA5 SMAN 5 Banda Aceh. Hal ini dapat dilihat dari peningkatan ketuntasan individual secara keseluruhan dari siklus 1 yaitu sebesar $70 \%$, siklus 2 sebesar $79 \%$, dan siklus 3 sebesar 95\%, sedangkan peningkatan ketuntasan klasikal secara keseluruhan untuk setiap siklus yaitu $65 \%$ pada siklus $1,80 \%$ pada siklus 2, dan $91 \%$ pada siklus $3 ; 2$ ) Aktivitas guru dan siswa selalu mengalami perbaikan setiap siklusnya, dimana pada siklus 1 terdapat 5 aktivitas yang belum sesuai dengan alokasi waktu yang telah ditetapkan, pada siklus 2 terdapat 3 aktivitas yang belum sesuai dengan alokasi waktu yang telah di tetapkan, dan pada siklus 3 seluruh aktivitas guru dan siswa telah sesuai dengan alokasi waktu yang ditetapkan; 3) Keterampilan guru dalam mengelola 
pembelajaran dengan menggunakan media laboratorium virtual PhET pada siswa SMAN 5 Banda Aceh kelas X-IA5 juga mengalami peningkatan setiap siklusnya. Secara umum keterampilan guru mengelola pembelajaran pada siklus 1 termasuk dalam katagori sedang dengan perolehan skor ratarata sebesar 2,5, siklus 2 termasuk katagori baik dengan perolehan skor rata-rata sebesar 3 dan siklus 3 termasuk katagori baik sekali dengan perolehan skor rata-rata sebesar 3,6. (Soewarno S., 2015)

Terdapat peningkatan hasil belajar siswa pada materi listrik dinamis setelah pembelajaran dengan media PhET. Hal ini didasarkan pada hasil belajar di tiap siklus, yaitu: Pada pembelajaran siklus I, 85,29\% siswa berhasil mencapai KKM dengan nilai rata-rata siswa 72,35; dan Pada pembelajaran siklus II, 89,47\% siswa berhasil mencapai KKM dengan nilai rata-rata siswa 76,97. Selain itu, siswa-siswa kelas X-1 SMA Negeri 1 Palangka Raya yang mengikuti kegiatan pembelajaran ini memberikan respon yang positif terhadap kegiatan pembelajaran. Berdasarkan hasil PTK ini, guru dapat memanfaatkan media PhET dalam membantu pelaksanaan tugas pokoknya. (P. Sinulingga, 2016).

Miskonsepsi tertinggi siswa XI IPA SMAN 2 Tanggul terletak pada konsep sumber tegangan, muatan listrik, hambatan listrik rangkaian seri, hukum I Kirchhoff, hambatan listrik, hambatan listrik rangkaian paralel, hukum Ohm, hukum II Kirchhoff, tegangan, arus dan kuat arus listrik dengan persentase secara berturut-turut $67 \%, 31,6 \%, 69,7 \%, 34,4 \%, 36,7 \%, 50 \%, 52,9 \%, 35,3 \%, 58,8 \%$, 42,6\%, 31,6\%. Konsepsi akhir siswa setelah dilakukan melalui simulasi PhET disertai LKS adalah siswa mengalami perubahan konsep yang sesuai dengan konsep yang diterima para ahli. Hal ini dibuktikan dengan penurunan persentase jumlah miskonsepsi yang dialami siswa yaitu pada konsep sumber tegangan, muatan listrik, hambatan listrik rangkaian seri, hukum I Kirchhoff, hambatan listrik, hambatan listrik rangkaian paralel, hukum Ohm, hukum II Kirchhoff, tegangan, arus dan kuat arus listrik dengan persentase secara berturutturut sebesar 53\%, 62.3\%, 50\%, 34.4\%, 44.2\%, 39.7\%, 27.9\%, $24.5 \%, 13.9 \%$, dan 22,8\%. (E. Andraini, 2015)

Hasil identifikasi awal miskonsepsi 97,82\% siswa mengalami miskonsepsi, setelah dilakukan pembelajaran dengan menggunakan media simulasi komputer, terjadi penurunan miskonsepsi sebesar $68,12 \%$ terhadap materi listrik dinamis. Hasil ini menunjukkan bahwa media simulasi komputer dapat meminimalkan kuantitas miskonsepsi siswa pada pembelajaran listrik dinamis. (M. Azzarkasyi, 2015).

Jadi, dari data-data hasil penelitian sebelumnya, membuktikan bahwa simulasi PhET memiliki peranan penting dalam mendukung pembelajaran materi rangkaian arus searah pada masa pandemi ini. Hal ini ditunjukan oleh data presentasi hasil belajar setelah menggunakan simulasi PhET di mana hasilnya rata-rata mengalami kenaikan. Selain itu, dari sisi misskonsepsi juga mengalami perubahan menjadi lebih baik. Siswa yang misskonsepsi jadi berkurang. Hal ini sangat bisa diterapkan khusunya pada saat pandemic seperti sekarang ini di mana siswa harus belajar di Rumah.

\section{Simpulan}

Setelah melakukan penelitian dalam bentuk review artikel ini, dapat disimpulkan bahwa simulasi PhET memiliki peranan penting dalam mendukung pembelajaran fisika khusunya materi rangkaian arus searah. Hal ini ditunjukan oleh data presentasi hasil belajar setelah menggunakan simulasi PhET di mana hasilnya rata-rata mengalami kenaikan. Selain itu, dari sisi misskonsepsi juga mengalami perubahan menjadi lebih baik. Siswa yang misskonsepsi jadi berkurang. Hal ini sangat bisa diterapkan khusunya pada saat pandemic seperti sekarang ini di mana siswa harus belajar di rumah dan kegiatan praktikum dapat digantikan untuk sementara menggunakan simulasi PhET ini.

\section{Referensi}

Andriani, E., dkk. 2015. Remedi Miskonsepsi Beberapa Konsep Listrik Dinamis pada Siswa SMA melalui Simulai PHET Disertai LKS. Jurnal Pendidikan Fisika.

Asyhar, Rayandra. 2012. Kreatif Mengembangkan Media Pembelajaran. Jakarta: Referensi.

Azzarkasyi, M., dkk. 2015. Dampak Penggunaan Media Simulasi Phet untuk Meminimalkan Kuantitas Miskonsepsi Siswa pada Pembelajaran Listrik Dinamis. Jurnal Pendidikan Sains Indonesia. 
Beniarti, T., dkk. 2018. Analisis Miskonsepsi Siswa Smk Pada Pokok Bahasan Rangkaian Listrik. Prosising Seminar Nasional Pendidikan Fisika 2018.

Didik, L.A., dkk. 2020. Identifikasi Miskonsepsi dan Tingkat Pemahaman Mahasiswa Tadris Fisika pada Materi Listrik Dinamis Menggunakan 3-Tier Diagnostic Test. Journal of Natural Science and Integration (JNSI).

Prasetyono, R.N. 2017. Miskonsepsi Mahasiswa Teknik Informatika pada Materi Kelistrikan. Jurnal Pendidikan IPA Veteran.

Putra, I.E., dkk. 2016. Analisis Miskonsepsi dan Upaya Remediasi Pembelajaran Listrik Dinamis dengan Menggunakan Media Pembelajaran Lectora Inspire dan Phet Simulation di SMAN Unggul Tunas Bangsa. Jurnal Pendidikan Sains Indonesia.

Sanjaya, Wina. 2012. Media Komunikasi Pembelajaran. Jakarta: Kencana Prenada Media Grup.

Sari, P.I., dkk. 2016. Penggunaan Discovery Learning Berbantuan Laboratorium Virtual pada Penguasaan Konsep Fisika Siswa. Jurnal Pendidikan Fisika dan Teknologi.

Sinulingga, P., dkk. 2016. Implementasi Pembelajaran Fisika Berbantuan Media Simulasi PhET untuk Meningkatkan Hasil Belajar Siswa Pada Materi Listrik Dinamis. Jurnal Penelitian dan Pengembangan Pendidikan Fisika (JPPPF).

Soewarno, S. 2015. Penerapan Media Laboratorium Virtual Phet pada Materi Hukum Ohm untuk Meningkatkan Hasil Belajar Siswa Kelas X-IA 5 SMAN 5 Banda Aceh. Jurnal Fisika Edukasi (JFE).

Sujanem, R., dkk. 2019. Pelatihan dan Pendampingan Pembuatan Media Simulasi Praktikum IPA SMP dengan Program Simulasi Phet. International Journal of Community Service Learning.

Taqwa, M.R.A., dan Rivaldo L. 2019. Pembelajaran Problem Solving Terintegrasi Phet: Membangun

Pemahaman Konsep Listrik Dinamis. Jurnal Teknologi Pendidikan.

Tarmizi, T., dkk. 2017. Penggunaan Metode Eksperimen untuk Mengatasi Miskonsepsi dan Meningkatkan Minat Belajar Peserta Didik pada Materi Rangkaian Listrik di Sma Negeri 1 Jaya Kabupaten Aceh Jaya. Jurnal IPA dan Pembelajaran IPA (JIPI).

Upayogi, I.N.T., dan Juliawan, I.W. 2019. Reduksi Miskonsepsi Melalui Pembelajaran Berbasis Virtual Lab. Journal of Teaching and Learning Physics (JoTaLP). 